\title{
Scientific-based approach pictorial storybook for eliciting creative thinking and collaborative skills
}

\author{
Annisa Yulistia \\ Universitas Lampung. Jalan Prof. Dr. Ir. Sumantri Brojonegoro, RW.No: 1, Gedong Meneng, Kec. \\ Rajabasa, Kota Bandar Lampung, Lampung 35141, Indonesia \\ * Corresponding Author. E-mail: annisa.yulistia@fkip.unila.ac.id \\ Received: 16 October 2017; Revised: 1 November 2019; Accepted: 11 November 2019
}

\begin{abstract}
This research aimed to develop a picture-story book based on scientific approach through the discovery learning method to improve students' creative thinking and collaborative skill. This research was a research and development which adopted a model proposed by Borg \& Gall which step including (1) research and information collecting, (2) planning, (3) developing preliminary product, (4) preliminary field testing, (5) main product revision, (6) main field testing, (7) operational product revision, (8) operational field testing, (9) final product revision, and (10) dissemination and implementation. The subject consisted of 50 students from the experimental class and 25 students from the control class. The result showed that (1) the picture-story book based on scientific approach through discovery learning method developed valid for use based on expert assessment and test result at the school with "very good" category, (2) the picture-story book based on scientific approach through discovery learning method could be used to improve students' creative thinking and collaborative skills.

Keywords: picture-story book, scientific approach creative thinking, collaborative

How to Cite: Yulistia, A. (2019). Scientific-based approach pictorial storybook for eliciting creative thinking and collaborative skills. Jurnal Prima Edukasia, 7(2), 172-181. doi:https://doi.org/10.21831/jpe.v7i2.16297

do https://doi.org/10.21831/jpe.v7i2.16297
\end{abstract}

\section{Introduction}

Indonesia is trying to realize the ideals of the nation in the field of education contained in the Preamble to the 1945 Constitution (Republik Indonesia, 2002). One of the ideals of the nation contained in the Preamble to the 1945 Constitution is to educate the nation's life. To educate the nation's life, of course, it must provide quality education for all children of the Indonesian. Improving the quality of education is not an easy task. It needs innovations and efforts in preparing the young generation to face the increasing complexity of the future.

Along with the increasing complexity of the development of the 21 st century, the demands are imposed on the world of education to produce quality education output and can compete globally. Elementary School (SD) is the main spotlight in the world of education because this phase is believed to be an important period of students' growth and development for six years in gaining knowledge and building the values of life that students are prepared for the future. Therefore, the current learning environment should foster the high-order thinking and attitudes that have benefits for students relating to the community and the environment. Thus, students are open and responsive to new perspectives, critical of questions that accommodate high order thinking, have good scientific attitudes, and have high creativity and innovate.

The development of the education system in Indonesia is constantly changing, especially the curriculum system at the elementary school. Learning activities implement the Curriculum 2013 (K13), an improvement from the previous curriculum. K13 is believed as an alternative method established by the government in efforts to improve the quality of education in Indonesia. In implementing K13 in elementary schools, learning activities are carried out thematically. It integrates the competencies of various subjects into a theme which then developed into several sub-themes (Peraturan Menteri Pendidikan dan Kebudayaan Republik Indonesia Nomor 69 Tahun 2013 tentang kerangka dasar dan struktur kurikulum sekolah/madrasah aliyah menengah atas, 2013) in the real world, from specific converted into practical and broad to providing 
space to explore creativity (John, 2015). The thematic learning refers to Piaget's theory that elementary school-age students are still at a concrete operational stage, where holistic is students' way of thinking (Ojose, 2008). It means looking into things as a whole or unity. Thus, the implementation of thematic learning is relevant applied at the elementary school, by considering the characteristics of ele-mentary school students who show cheerfulness, happiness, and full of dreams.

The implementation of K13 encourages the learning to use integrated thematic learning. Integrated thematic is a sub-model of thematic learning. Integrated thematic learning departs from the view of (Fogarty, 2009, p. 12), states that integrated thematic learning is part of ten integrated learning models. The Ministry of Education and Culture refers to the integrated model, namely by integrating several disciplines into a theme.

Aiming to create quality education, the application of thematic learning will be better through the application of the scientific approach. Learning activities with a scientific approach consists of observing, asking, trying or experimenting, processing, displaying, associating or reasoning, and communicating. Learning with a scientific approach promises a quality educational product that meets the demands of the times due to scientific approach lead to activities of scientific and, at the same time, encourage children to work scientifically. Thus, learning must able to develop more than just knowledge but also the process, creativity, attitude, and application.

Learning activities is better to insert learning methods that support the scientific approach, in which learning activities may be through observing, asking, trying, processing, displaying, associating, and communicating activities. (Daryanto, 2014, p. 51) argues, learning with a scientific approach is learning which aimed the students can actively construct concepts, laws or principles through stages such as observing, formulating problems, proposing/formulating hypotheses, collecting information/experiments, associating/processing information, and communicating. The opinion implies that the scientific approach has several stages in line with the scientific method. Supported by Regulation The Ministry of Education and Culture (Peraturan Menteri Pendidikan dan Kebudayaan nomor 103, tahun 2014, tentang pembelajaran pada pendidikan dasar dan pendidikan menengah,
2014) No.103 of 2014 Article 2, explains that learning uses approaches, strategies, models, and methods that refer to several activities with characteristics supporting the scientific approach. The characteristics are (1) interactive and inspireing; (2) fun, challenge, and motivating students to participate actively; (3) contextual and collaborative; (4) provide sufficient space for students' initiative, creativity, and independence; and (5) according to students' talents, interests, abilities, and physical and psychological development (Peraturan Menteri Pendidikan dan Kebudayaan nomor 103, tahun 2014, tentang pembelajaran pada pendidikan dasar dan pendidikan menengah, 2014).

There are several methods in supporting the activities of the scientific approach, such as discovery learning, which is one of the methods recommended in K13. The discovery learning method refers to the theory of constructivism, where students learn to build their knowledge through an invention in their assignment. (Prasetyo, 2011), explains two forms of discovery learning method, namely free discovery and guided discovery. There is a slight difference between the two. Free discovery, students are required to do free discovery activities without the influence of the teacher as a facilitator, while guided discovery is more provided the help/guide by the teachers (blended student-teacher centred). Thus, hands-on/minds-on learning will appear in learning activities so that learning will be more meaningful for students.

The government provides the K13 theme book as teaching material for teachers and students, as well as for schools that have implemented K13. Viewed from the field of the scientific approach, the theme book has not been maximized in facilitating the stages of the scientific approach. The material in the learning content presented in the theme book is not balanced. Also, the theme book is less flexible to display interesting thematic learning. The division of the lesson content is visible, which making the essence of thematic learning is less noticed. Also, the theme book is not giving pictures and interesting colour, this does not reflect the lives of students who are cheerful, enthusiastic, and full of curiosity. Thus, it needs for innovative teaching materials of books as learning materials in learning activities. Supported by Suwandi and Masruri (2016, p. 89), the developing national history picture book with an integrated thematic approach is appropriate for use in learning and is effective in increasing students' understanding of 
grade IV elementary school. Other research, Budiarti and Haryanto (2016, p. 241) develops media of comic books which can increase students' motivation and reading comprehension skills.

In this 21 st century, creativity is a skill that must be possessed by an individual. To be creative, one must be able to think creatively. Creativity consists of thinking that is flexible, fluent, unique and unusual in different situations (Türkmen \& Sertkahya, 2015, p. 78). Oppezzo and Schwartz (2014) added, creativity also has the potential to make a positive contribution to society. Thus, creative thinking needs to build in a person because they contribute to social life. The purpose of creative thinking is to encourage curiosity and make diverse differences (Anwar et al., 2012) generate diverse ideas and solve problems creatively (Russ \& Wallace, 2013, p. 137).

Not only creative thinking that is needed in competing in a global society, but there are also other important skills that students must possess since elementary school age. The ability of students to interact with the social environment becomes the most fundamental for students in building cooperation or collaboration. Supported by Ansari and Malik (2013), identified seven skills needed in this century, such as collaboration. Collaboration means emphasizing learning in groups. (Piirto, 2011, p. 35) explains, working in a group will create a sense of interdependence among group members, each group member has rules, and work must finish. Also, the members must get rid of being arrogant or selfish to avoid bad things when working together.

In collaborative activities, the atmosphere of learning in the classroom must reflect active learning because students are required to collaborative and blended to all class members. Students who work socially (collaboratively) imply the need to learn to be open (developing ideas and sharing information); this is not only important in the context of self-reflection but also in working with fellow friends (Toros \& Medar, 2015); Felder and Brent (1996) also stated that collaborative activities lead to positive interdependence between students; individual accountability; face to face interaction; the use of appropriate cooperative skills and work in group (Said et al., 2016, p. 68).

Efforts to improve the ability of creative thinking and collaborative attitudes of students required an interesting teaching material innovation. A scientific approach-based picture book is expected to be able to answer the teacher's need for teaching materials with a story that refers to discovery learning. (Mitchell et al., 2002) described a picture storybook as a book in which there are interrelated pictures and texts. Supported by (Huck et al., 2000), picture books can convey messages in two ways; through illustrations and writing. This opinion provides an understanding that picture books have a primary key. Namely, there is a relationship between pictures and messages conveyed through text. The illustrated storybooks in this research development are classified as illustrated books and one form of children's literature that entertains and provides scientific knowledge through the content of the material presented in the story. A research conducted by Saputro and Soeharto (2015, p. 71), found out that comic books character-based in thematic-integrative learning of grade IV elementary school, are suitable for use in learning. Comic books are the same as picture books. The similarities are interconnected images and writings. However, the developed picture books refer more to the scientific approach, where there are scientific steps in the story that encourage students to do these stages. So, the learning will be more meaningful by doing activities directly to find concepts or material of learning.

Thus, the particular research developed a supplementary learning book of a picture book based on a scientific approach with discovery learning methods, especially on the theme 7 "Energy and Change" to improve students' creative thinking and collaborative skill in learning in class III on the theme 7 th.

The objectives the research were to (1) produce a picture book based on a scientific approach through discovery learning methods that are suitable for use in third-grade elementary school learning, and (2) produce a picture book based on a scientific approach through discovery learning that used to improve students' creative thinking and collaborative skill.

The benefits of the research were (1) for students, providing books as a source of learning that is more interesting and can improve students' creative thinking and collaborative skill. Moreover, it can provide a fun learning experience with learning methods that refer to the illustrated storybook for students. (2) Providing teaching materials in the form of books supporting learning activities that can improve students' creative thinking and collaborative skill. 


\section{Method}

This research was a research and development which adopted a model proposed by Gall et al. (2003). The research consisted of 10 steps. They were (1) research, and information collecting, (2) planning, (3) develop preliminary product, (4) preliminary field testing, (5) main product revision, (6) main field testing, (7) operational product revision, (8) operational field testing, (9) final product revision, and (10) dissemination and implementation (Fani \& Sukoco, 2019; Pujayanto et al., 2017).

The trial test of the product development of a picture book was through several stages, namely: (1) limited trials with nine subjects in class III and one teacher in class III at SD Joannes Bosco, (2) the trial was expanded with 15 subjects of class III students and one teacher class III at SD N Serayu, and (3) operational trials. The test subjects in the operational test were; 50 students of class III at SD N Serayu and SD Joannes Bosco played as the experimental class, and 25 students of SD Muhammadiyah Gendeng played as the control class.

Data collection instruments were the scale of product assessment for material and linguist experts, the scale of teacher responses and student responses, questions of creative thinking ability, and the scale of students' collaborative attitudes.

In this study, the data were analyzed to obtain a feasible picture book based on a scientific approach through discovery learning. The step was data of scores from experts obtained through the product feasibility assessment sheet. The total of the obtained actual score is then converted to a five scale quantitative data. Assessments stated as to meet the criteria if the minimal category achieved was "good." According to (Widoyoko, 2012), the scores are converted to scores on a five scale concerning Table 5.

Table 1. Score Conversion on Scale 5

\begin{tabular}{lcc}
\hline \multicolumn{1}{c}{ Interval } & Score & Category \\
\hline $\mathrm{X}>(\mathrm{Xi}+1,8 \mathrm{Sbi})$ & $\mathrm{A}$ & Excellent \\
$\mathrm{Xi}+0,6 \mathrm{Sbi}<\mathrm{X} \leq \mathrm{Xi}+1,8 \mathrm{Sbi}$ & $\mathrm{B}$ & Good \\
$\mathrm{Xi}-0,6 \mathrm{Sbi}<\mathrm{X} \leq \mathrm{Xi}+0,6 \mathrm{Sbi}$ & $\mathrm{C}$ & Fair \\
$\mathrm{Xi}-1,8 \mathrm{Sbi}<\mathrm{X} \leq \mathrm{Xi}-0,6 \mathrm{Sbi}$ & $\mathrm{D}$ & Poor \\
$\mathrm{X} \leq \mathrm{Xi}-1,8 \mathrm{Sbi}$ & $\mathrm{E}$ & Very Poor \\
\hline
\end{tabular}

Where:

$\mathrm{X}=$ obtained score

$\mathrm{Xi}=$ ideal mean (maximum score + minimum score)

$\mathrm{Sbi}=$ ideal standard deviation (maximum score minimum score)

\section{Result and Discussion}

The results of the study began with an explanation of the first procedure, namely, the results of the preliminary study, collecting information and planning results. The results of the preliminary study and collecting information consist of the results of the literature study, the results of the need analysis for teaching materials by students, teacher interviews, results of observations of the curriculum 2013 learning activities in class III, and the documentation of student learning outcomes. Second, the planning stage by conducting the development of research instruments. Third, developing the initial product draft, after that, it is validated by linguists and material experts. The product feasibility assessment by linguists is presented in Table 2.

Table 2. Results of Product Value by Linguists

\begin{tabular}{lcc}
\hline \multicolumn{1}{c}{ Aspect } & Score & Value \\
\hline Story Element & 62 & $\mathrm{~A}$ \\
Illustration & 37 & $\mathrm{~A}$ \\
Format & 65 & $\mathrm{~A}$ \\
Anatomy of books & 71 & $\mathrm{~B}$ \\
Feasibility of display & 72 & $\mathrm{~B}$ \\
Feasibility of language & 28 & $\mathrm{~B}$ \\
Criteria of title & 31 & $\mathrm{~A}$ \\
Total & 363 & $\mathrm{~A}$ \\
\hline
\end{tabular}

Based on Table 2, the results of the product values by linguists indicated that the total score of 363 with A category was "excellent." This result showed that the product has passed the minimum score to obtain the value of $\mathrm{B}$. Thus, the product was feasible in terms of language, and can continue to have the further test at school.

Not only the assessment in terms of language, but the content of the material contained in a picture book based on a scientific approach also needs attention. Therefore, an assessment by a material expert is also carried out. The results of the product assessment by material experts are presented in Table 3.

Table 3. Result of Product Value by Material Expert

\begin{tabular}{lcc}
\hline \multicolumn{1}{c}{ Aspect } & Score & Value \\
\hline The suitability of the description of & 22 & A \\
the material with KI KD & 47 & A \\
Material accuracy & 49 & B \\
Learning support material & 38 & A \\
Feasibility of display & 34 & A \\
The activity of scientific approach & 24 & B \\
and discovery learning & 213 & A \\
Language (reading level) & & \\
Total & & \\
\hline
\end{tabular}


Based on Table 3, the results of the product values by material experts indicated that the total score of 213 with A category was "excellent." This result showed that the product had passed the minimum score to obtain the value of B. Thus, the product was feasible in terms of language, and can continue to have further test at school.

The next stage was a limited trial, provided to 9 students of class III, Joannes Bosco Elementary School and the guardian teacher of class III. The obtained data were the calculation results of the scores of student and teacher responses. The scores of student and teacher responses in limited trials are presented in Table 4.

Table 4. Scores of Student and Teacher Responses in Limited Trials

\begin{tabular}{lcc}
\hline Response & Total of Score & Value \\
\hline Teacher & 59 & B \\
Students & 46,89 & B \\
\hline
\end{tabular}

Based on Table 4, the results of teacher and student responses in limited trials obtained the value of $\mathrm{B}$, in the "good" category. This result showed that the product of the storybook based on the scientific approach through the discovery learning method obtained good value. However, it should make improvements with the aim the books can be effectively used to improve students' creative thinking and collaborative skills.

After the improvements, then, the product was used to find out the responses of students and teachers in the expanded trial by adding research subjects, which are 15 students and one teacher of grade III elementary school. The score of teacher and student responses in this trial are presented in Table 5.

Table 5. Scores of Student and Teacher Responses in Expanded Trials

\begin{tabular}{lcc}
\hline Response & Total of Score & Value \\
\hline Teachers & 71 & $\mathrm{~A}$ \\
Students & 53,6 & $\mathrm{~A}$ \\
\hline
\end{tabular}

Based on Table 5, the results of teacher and student responses showed the increasing score in the expanded trial, which from the value of $B$, in the "good" category increased to the value of B, in the "excellent" category. This shows a better increase in student responses in the expanded trials because revisions were made based on student and teacher responses.

After obtained the teacher and student responses in limited trials and expanded trials, empirical tests or operational trials were employed to obtain the value of creative thinking and the value of students' collaborative skills before and after learning using the developed products. The results obtained data on the pretest and posttest the ability of creative thinking and collaborative skills of students in the control and experiment class. The results of increasing creative thinking and collaborative skills are presented in Table 6 and Table 7.

Table 6. Increasing the Creative Thinking Skill of $S `$ tudents

\begin{tabular}{lllll}
\hline Class & N pretest & N Posttest & Gain & Criteria \\
\hline KK & 66,22 & 72,34 & 0,45 & Medium \\
KE 1 & 67,30 & 86,98 & 0,73 & High \\
KE 2 & 64,63 & 86,87 & 0,76 & High \\
\hline
\end{tabular}

Table 7. Increasing the Collaborative Skill of Students

\begin{tabular}{lllll}
\hline Class & N pretest & N Posttest & Gain & Criteria \\
\hline KK & 65,96 & 71,96 & 0,46 & Medium \\
KE 1 & 66,60 & 85,08 & 0,73 & High \\
KE 2 & 64,04 & 86,64 & 0,81 & High \\
\hline
\end{tabular}

Based on Table 6 and Table 7, the score of pretest and posttest used to find out the gain value, which then used to see the effectiveness of using the developed products in learning. The gain value is obtained by comparing the differences between the score of pretest and posttest. The average gain score between the control and experimental classes is presented in Figure 1.

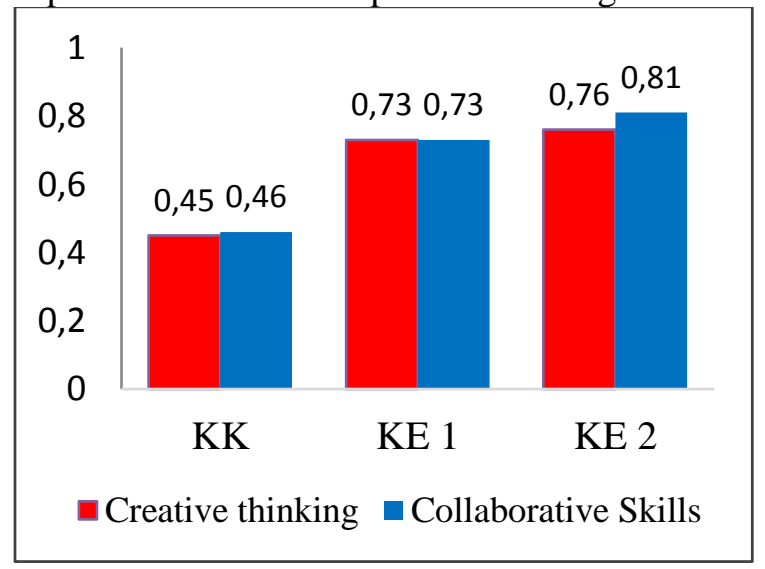

Figure 1. Mean Gain of Creative Thinking and Collaborative Skills

The data in Figure 1 showed that the mean gain in the experimental class 1 and experimental class 2 is higher than the control class. Then, the picture books based on scientific approach through discovery learning methods stated as effective to improve students' creative thinking and collaborative skills. 
Data Analysis of Creative Thinking and Collaborative skills

Based on the data of students' creative thinking and collaborative skill, there are differences in creative thinking and collaborative skills between the experimental class and the control class. It conducted a Manova (multivariate of analyze) test aiming to find out whether there are differences of increasing the creative thinking and collaborative skills of students in the two classes. Before the MANOVA hypothesis test, the assumption test of normality and homogeneity test conducted and then continued to correlation test.

Multivariate normality

The assumption of normality carried out to meet the assumptions that the data are from normally distributed populations. A multivariate normality test is conducted by determining the cost of Mahalanobis Distance using the SPSS 23.0 program at a significance level of 0.05 . Criteria for decisions was, if the significance value $<0.05, \mathrm{H} 0$ is accepted. This means the data is normally distributed. Hypothesis formulation in the normality test was, $\mathrm{H} 0=$ data from normally distributed populations, and, $\mathrm{H} 1$ = data not from normally distributed populations.

Multivariate normality test used SPSS 23. The normality test results showed that in the control class, experimental class 1 and experimental class 2 showed a significance value of 0,000 . It showed the significance value $<0.05$, where the conclusion of the multivariate normality test was the data from the normal distribution population if the significance value $<0.05$. Thus, it concluded that the data were from normally distributed populations.

\section{Homogeneity of Variant Matrix}

The assumption in MANOVA was the assumption of the homogeneity of the covariance matrix. The homogeneity test of the covariance matrix was the Box's M test using the SPSS 23 program. The result of the Box's M Test showed that the significance value is 0.112 , where the value is higher than 0.05 . So, the variance-covariance matrix of the variable of creative thinking and collaborative skills was homogeneous.

\section{Correlation Test}

Correlation coefficient test was performed to determine the relationship between the two variables; creative thinking and collaborative skills. Hypothesis formulation in the correlation test was; $\mathrm{H}_{0}$, there is a relationship between the two variables. H1, there is no relationship between the two variables. Correlation test used Pearson Correlation of SPSS 23 program at a significance level of 0.05 . The criteria for the decision was the significance value $<0.05$. Then, Ho is accepted. This means there is a relationship between the two variables.

The results of the correlation test showed that the value of the correlation coefficient between the gain value of creative thinking and collaborative skills was 0.835 with a significance value of 0,000 . Thus, sig. Correlation is less than 0.05 when compared with alpha $(5 \%)$. Then, the decision was $\mathrm{H}_{0}$ is rejected. In sum, the correlation coefficient was significant. The variable of creative thinking and collaborative skills had a positive correlation. And, it continued to the MANOVA test.

\section{Manova Hypothesis Test}

This test aimed to determine whether the developed picture book based on the scientific approach can significantly increase the creative thinking and collaborative skills of students or not. The decision of the null hypothesis $\left(\mathrm{H}_{0}\right)$ and the alternative hypothesis $\left(\mathrm{H}_{1}\right)$ in this study are; $\mathrm{H}_{0}$, there are no differences in increasing creative thinking and collaborative skills between the experimental class and the control class. $\mathrm{H}_{1}$, there are differences in the increasing creative thinking and collaborative skills of students between the experimental class and the control class. Criteria for accepting and rejecting $\mathrm{H}_{0}$ at a significance level of 5\% using significance, i.e. if significance $>0.05$, then $\mathrm{H}_{0}$ is accepted, if significance $<0.05$, then $\mathrm{HO}$ is rejected.

Table 8. Results of the Manova Hypothesis Test

\begin{tabular}{lcc}
\hline & Value & Sig. \\
\hline $\begin{array}{c}\text { Hotelling's } \\
\text { Trace }\end{array}$ & 21,598 &, 000 \\
\hline
\end{tabular}

Table 8 showed that the significance value of the Hotelling's Trace test is $0,000<0.05$. So, concluded that Ho is rejected and $\mathrm{H} 1$ is accepted. This means, there are significant differences in students' creative thinking and collaborative skills between the experimental class and the control class. The experimental class 1 and experimental class 2 have higher creative thinking and collaborative skills that are higher than the control class.

The results showed that the illustrated storybook based on the scientific approach through the discovery learning method significantly 
affected the students' creative thinking and collaborative skills. In line with the opinion of (Elia et al., 2010, p. 3), in reading stories, students can develop new ideas, structures, and schemes, as well as to attain knowledge at a higher level. Argued by (Bybee, 2002, p. 39), students can learn well when doing meaningful assignments, engaging in experimental or exploration activity on an interesting topic. Students do not only hands-on activities but also demand minds-on activity. In learning, it is not enough to only use handwork, but also use thoughts and feelings. It shows that picture books based on scientific approach through discovery learning methods may use in learning and may improve students' creative thinking and collaborative skills.

Considering the basis of the story using a scientific approach through discovery learning methods that prioritize experimental activities, the developed products were in line with the theory that shows the significant increase of the creative thinking and collaborative skills. Pringle and Lamme (2005, p. 3) stated, picture books arranged on the age of students will provide learning support visually through pictures and words. Confirmed by Lin (2012, p. 40), students like picture books. A good picture book can inspire students' positive thoughts about humans and phenomena.

Not only the scientific approach but illustrated storybooks also provide discovery learning methods that provide space for students to carry out experimental activities of the product. Arends and Kilcher (2010, p. 382) stated discovery learning is a learning activity that facilitates students to learn through inquiry and explore various things by building students' experiences. The opinion provides an understanding that discovery learning gives students space to explore their thoughts through investigative or experiment activities in discovering the principles, facts, or concepts of the subject being studied. Supported by Singaravelu (2012, p. 57), discovery learning occurs when students are not given knowledge or conceptual understanding. So, students must find it independently. Thus, the teacher must be able to foster a coherent learning environment and create a relationship and association between the initial knowledge of students, and the knowledge will learn on learning.

Besides increasing the creative thinking, the collaborative skills of students also increased significantly. In line with (Al-Somadi, 2012, p. 535), literature can help students to learn about the real world in a fun and interesting way, and understanding the environment around and relationships with others in social life. Also, Turan and Ulutas (2016) states, storybooks facilitate students in character education. The character is collaboration because the emergence of this attitude comes from the personal character of the students that performed in the act.

Learning activities that prioritize group activities will increase the students' collaborative skills. This statement is in line with the assumption of Suprijono $(2009$, p. 46) that cooperative learning has developed to increase academic collaboration among students, building positive relationships, develop self-confidence, and increaseing academic ability through group activities.

Using textbooks for students can improve the collaborative skills that are seen from the relationship of students with others in social life in the classroom environment. Students can imitate the behaviour of characters that reflect the behavior of scientific attitudes. This is following the opinion of Pehrsson and Pehrsson (2007) that each child has experience with character as an alter ego which, in turn, be a role model for a child.

Besides obtain a meaningful learning experience, students also obtain lessons to understand new vocabulary in their world. Especially on scientific material that contains scientific words, those might not yet be known to students. (Ward, 2010) indicates that language needs to be taught in an understood context, with simple vocabulary and picture instructions in picture storybooks.

Limitations of the research and development were: (1) The material developed in the storybook based on scientific approach through discovery learning is only to the theme "Energy and Change"; (2) the product of picture book based on scientific approach through discovery learning focuses on developing students' collaborative skills, although does not limit the development of other scientific attitudes; and (3) Developing storybook based on scientific approach through discovery learning reached only the limited dissemination stage, namely at SD Joannes Bosco, SD N Serayu, and SD Muhammadiyah Gendeng.

\section{Conclusions}

The developed picture books based on scientific approaches through discovery learning, that aimed to improve the students' creative thinking and collaborative skills, are feasible to 
use based on linguists and material experts in the "excellent" category.

Picture books based on scientific approaches through discovery learning are effective in improving the students' creative thinking and collaborative skills of third-grade elementary school. The fact is based on operational trials that show the value of sig. $<0.05$. It means that there are significant differences in the students' creative thinking and collaborative skills between students learn using products and without using products.

The developing picture book based on a scientific approach through discovery learning to improve the students' creative thinking and collaborative skills of third-grade elementary school has been tested for feasibility and effectiveness. Therefore, it is suggested to teachers to (1) use a picture book based on a scientific approach through discovery learning as a learning material for students in learning activities to improve the students' creative thinking and collaborative skills, and (2) using the product, it is important to consider the time, aiming the entire scientific approach and discovery activities can be completed. Moreover, equipment and tools for conducting experimental activities should be prepared well in advance before learning activities.

\section{References}

Al-Somadi, M. M. F. (2012). The effect of a story-based programme on developing moral values at the kindergarten stage. Interdiciplinary Journal of Contemporary Research in Buisiness, 4(7), 534-559.

Ansari, S. U., \& Malik, S. K. (2013). Image of an effective teacher in 21st century classroom. Journal of Educational and Instructional Studies in the World, 3(4), 61-68.

http://www.wjeis.org/FileUpload/ds21723 2/File/08.ansari.pdf

Anwar, M. N., Aness, M., Khizar, A., Naseer, M., \& Muhammad, G. (2012). Relationship of creative thinking with the academic achievements of secondary school students. International Interdisciplinary Journal of Education, 1(3), 44-47. http://wsw.iijoe.org/volume1/IIJE_01_03 _12.pdf

Arends, R. I., \& Kilcher, A. R. (2010). Teaching for student learning: Becoming an accomplished teacher. In Routledge.
Taylor \& Francis e-Library. https://doi.org/10.4324/9780203866771

Budiarti, W. N., \& Haryanto, H. (2016). Pengembangan media komik untuk meningkatkan motivasi belajar dan keterampilan membaca pemahaman siswa kelas IV. Jurnal Prima Edukasia, 4(2), 233-242.

https://doi.org/10.21831/jpe.v4i2.6295

Bybee, R. W. (2002). Learning science and the science of learning: Science educators, essay collection.

Daryanto, D. (2014). Pendekatan pembelajaran saintifik Kurikulum 2013. Gava Media.

Elia, I., van den Heuvel-Panhuizen, M., \& Georgiou, A. (2010). The role of pictures in picture books on children's cognitive engagement with mathematics. European Early Childhood Education Research Journal, 18(3), 275-297. https://doi.org/10.1080/1350293X.2010.5 00054

Fani, R. A., \& Sukoco, P. (2019). Volleyball learning media using method of teaching games for understanding adobe flashbased. Psychology, Evaluation, and Technology in Educational Research, 2(1), 34. https://doi.org/10.33292/petier.v2i1.6

Felder, R. M., \& Brent, R. (1996). Navigating the bumpy road to student-centered instruction. College Teaching, 44(2), 4347.

https://doi.org/10.1080/87567555.1996.99 33425

Fogarty, R. (2009). How to integrate the curricula. Corwin.

Gall, M. D., Gall, J. P., Borg, W. R. D., \& Gall, J. P. (2003). Educational research: An introduction (7th ed.). Pearson Education Inc.

Huck, C. S., Hepler, S., Hickman, J., \& Kiefer, B. Z. (2000). Children's literature in the elementary school. Mcgraw-Hill College.

John, Y. J. (2015). A "new" thematic, integrated curriculum for primary schools of Trinidad and Tobago: A paradigm shift. International Journal of Higher Education, 4(3). https://doi.org/10.5430/ijhe.v4n3p172

Lin, R. (2012). A study of creative thinking for children's picture book creation. IERI Procedia, 2, 36-42. 
https://doi.org/10.1016/j.ieri.2012.06.048

Peraturan Menteri Pendidikan dan Kebudayaan Republik Indonesia Nomor 69 Tahun 2013 tentang kerangka dasar dan struktur kurikulum sekolah/madrasah aliyah menengah atas, Pub. L. No. 67, Peraturan Menteri Pendidikan dan Kebudayaan Republik Indonesia (2013).

Peraturan Menteri Pendidikan dan Kebudayaan nomor 103, tahun 2014, tentang pembelajaran pada pendidikan dasar dan pendidikan menengah, Pub. L. No. 103, Peraturan Menteri Pendidikan dan Kebudayaan Republik Indonesia (2014).

Mitchell, D., Waterbury, P., \& Casement, R. (2002). Children's literature: An invitation to the world. Allyn \& Bacon.

Ojose, B. (2008). Applying Piaget's theory of cognitive development to mathematics instruction. The Mathematics Educator, 18(1)

http://tme.journals.libs.uga.edu/index.php/ tme/article/view/193

Oppezzo, M., \& Schwartz, D. L. (2014). Give your ideas some legs: The positive effect of walking on creative thinking. Journal of Experimental Psychology: Learning, Memory, and Cognition, 40(4), 11421152. https://doi.org/10.1037/a0036577

Pehrsson, D.-E., \& Pehrsson, R. S. (2007). Language fantasy approach: A therapeutic intervention by creating myths with children. Journal of Poetry Therapy, 20(1), 41-49. https://doi.org/10.1080/088936707012547 68

Piirto, J. (2011). Creativity for 21st century skills: how to embed creativity into the curriculum. SensePublishers.

Prasetyo, Z. K. (2011). Pengembangan perangkat pembelajaran sains terpadu untuk meningkatkan kognitif, keterampilan proses, kreativitas serta menerapkan konsep.

Pringle, R., \& Lamme, L. (2005). Using picture storybooks to support young children's science learning. Reading Horizons: A Journal of Literacy and Language Arts, 46(1).

https://scholarworks.wmich.edu/reading horizons/vol46/iss1/2

Pujayanto, P., Supurwoko, S., Radiyono, Y., \&
Adi, D. W. (2017). Development of problem-based learning material for physics mathematics and its implementation. International Journal of Science and Applied Science: Conference Series, $1(1), \quad 16$. https://doi.org/10.20961/ijsascs.v1i1.5104

Republik Indonesia. (2002). Undang-Undang Dasar Negara Republik Indonesia Tahun 1945. Sekretariat Jenderal MPR RI.

Russ, S. W., \& Wallace, C. E. (2013). Pretend play and creative processes. American Journal of Play, 6(1), 136-148.

Said, I. M., Sutadji, E., \& Sugandi, M. (2016). The scientific approach-based cooperative learning tool for vocational students vocation program of autotronic (automotive electronic) engineering. IOSR Journal of Research \& Method in Education (IOSR-JRME), 6(3), 67-73. https://doi.org/10.9790/7388-0603046773

Saputro, H. B., \& Soeharto, S. (2015). Pengembangan media komik berbasis pendidikan karakter pada pembelajaran tematik-integratif kelas IV SD. Jurnal Prima Edukasia, 3(1), 61-72. https://doi.org/10.21831/JPE.V3I1.4065

Singaravelu, G. (2012). Discovery learning strategies in English. Journal on English Language Teaching, 2(1), 57-62. https://doi.org/10.26634/jelt.2.1.1620

Suprijono, A. (2009). Cooperative learning: teori \& aplikasi PAIKEM. Pustaka Pelajar.

Suwandi, I. K., \& Masruri, M. S. (2016). Pengembangan picture book sejarah nasional dengan pendekatan tematik terpadu untuk kelas IV sekolah dasar. Jurnal Prima Edukasia, 4(1), 79. https://doi.org/10.21831/jpe.v4i1.7747

Toros, K., \& Medar, M. (2015). Social work students' thoughts on self-reflection: A qualitative study based on reflective journaling. International Journal of Humanities and Social Science, 5(3).

Turan, F., \& Ulutas, I. (2016). Using storybooks as a character education tools. Journal of Education and Practice, 7(15). https://www.iiste.org/Journals/index.php/J EP/article/view/30887

Türkmen, H., \& Sertkahya, M. (2015). Creative thinking skills analyzes of vocational high school students. Journal of Educational 
Jurnal Prima Edukasia, 7 (2), 2019 - 181

Annisa Yulistia

and Instructional Studies, 5(1), 74-84. http://www.wjeis.org/FileUpload/ds21723

2/File/10.hakan_turkmen..pdf

Ward, H. (2010). Buku pengajaran sains berdasarkan cara kerja otak. Indeks.

Widoyoko, E. P. (2012). Teknik penyusunan instrumen penelitian. Pustaka Pelajar. 